\title{
alsingat
}

JURNAL PENELITIAN BAHASA, SASTRA, DAN

BUDAYA ARAB

P-ISSN: 2615-7241 | E-ISSN: 2721-480X // Vol. 2 No. 2 | 126-136

(1) https://ejournal.upi.edu/index.php/alsuniyat/index

\section{PENGGUNAAN MODEL PEMBELAJARAN DISCOVERY LEARNING PADA MATERI MUBTADA KHABAR KELAS VII MTS AL-MUSYAWARAH LEMBANG}

\author{
Fina Khairunisa \\ MTs Al-Musyawarah Lembang Bandung, Indonesia \\ E-mail: zahirafina@gmail.com
}

\begin{abstract}
:
This research is motivated by the problems experienced by students in learning material mubtada khabar preachers who are difficult to understand in their implementation. The method used by the teacher is less effective. In this situation resulted in students tend to be more passive in teaching and learning activities. However, different conditions exist in Al-Musyawarah Lembang MTs, where students are very enthusiastic about the preaching material, because of the teacher's efforts to apply the discovery learning model. The purpose of this study was to describe the discovery learning model of the seventh-grade students of Al-Musyawarah Lembang preaching material mubtada khabar. Based on the results of the study: planning on the material of mubtada khabar in using the discovery learning model with the 2013 curriculum syllabus, the process on the material of Khubtada Khabar in using the discovery learning model students can focus on during the learning process, so students can apply the material quite well, evaluating the material mubtada khabar in using discovery learning models with assessment techniques namely oral and written tests.

Keywords:

Discovery learning; Learning model; Mubtada khabar
\end{abstract}

\begin{abstract}
Abstrak:
Penelitian ini dilatarbelakangi oleh permasalahan yang dialami siswa dalam mempelajari materi mubtada khabar yang dalam pelaksanaannya sulit untuk dipahami siswa. Metode yang digunakan guru kurang efektif. Dalam situasi ini mengakibatkan siswa cenderung lebih pasif dalam kegiatan belajar mengajar. Akan tetapi, kondisi berbeda ada di MTs Al-Musyawarah Lembang, dimana siswa sangat antusias terhadap materi mubtada khabar, dikarenakan adanya upaya guru dengan menerapkan model pembelajaran discovery learning. Tujuan penelitian ini adalah untuk menggambarkan model pembelajaran discovery learning pada materi mubtada khabar kelas VII MTs Al-Musyawarah Lembang. Berdasarkan hasil penelitian: perencanaan pada materi mubtada khabar dalam menggunakan model pembelajaran discovery learning dengan silabus kurikulum 2013, proses pada materi mubtada khabar dalam menggunakan model pembelajaran discovery learning siswa dapat fokus selama pembelajaran berlangsung, sehingga siswa dapat mengaplikasikan materi dengan cukup baik, evaluasi pada materi mubtada khabar dalam menggunakan model pembelajaran discovery learning dengan teknik penilaian yaitu tes lisan dan tes tulisan.
\end{abstract}

Kata Kunci:

Discovery learning; Model pembelajaran; Mubtada khabar

\section{PENDAHULUAN}

Bahasa Arab merupakan salah satu mata pelajaran yang banyak diselenggarakan di sekolah-sekolah yang berbasis keislaman, karena mata pelajaran bahasa Arab sangat penting dipelajari siswa untuk memberi bekal pengetahuan agar dapat memahami alquran dan hadis. Dalam pembelajaran bahasa Arab terdapat ilmu naḥwu (sintaksis). Adapun ilmu naḥwu disebut juga dengan bapak ilmu yang mempelajari susunan dan kedudukan kata di dalam suatu kalimat. 
ALSUNIYAT: Jurnal Penelitian Bahasa, Sastra, dan Budaya Arab

Menurut Al-Jurjani (2003:236) naḥwu adalah ilmu yang memuat berbagai aturan yang dapat mengetahui kondisi susunan-susunan kalimat bahasa Arab dari i'rāb dan bina atau selain dari keduanya. Dikatakan juga bahwa naḥwu adalah ilmu yang bisa mengetahui kedudukan atau susunan kalimat dari segi i'lāl.

Selain itu, menurut Al-Ghalayini (2005:5) ilmu naḥwu adalah suatu ilmu tentang pokokpokok yang dengannya dapat diketahui kata-kata Bahasa Arab baik dari segi i'rāb maupun binanya. Didalamnya juga diketahui apa yang terjadi pada harakat akhir suatu kata baik rafa', nașab, jar, maupun jazm atau tetap saja pada suatu keadaan setelah kata tersebut tersusun di dalam suatu kalimat. Dalam pembelajaran bahasa Arab sering kali kita jumpai kalimat sempurna dan kalimat tidak sempurna, misalnya kalimat yang didahului oleh isim yang biasa disebut dengan Jumlah Ismiyyah atau Mubtada dan Khabar. Kalimat yang didahului oleh isim, tanda harakat akhir rafa" dan berada di awal kalimat biasa disebut dengan mubtada dan isim yang menjelaskannya disebut khabar. Mubtada dan khabar merupakan suatu kesatuan yang tidak dapat dipisahkan.

Kendati demikian, dalam mata pelajaran bahasa Indonesia, jika mubtada sebagai subjek dan khabar sebagai predikat yang menjadi penjelas kalimat sebelumnya. Hukum asal mubtada adalah kalimat yang didahulukan dan hukum asal khabar adalah kalimat yang diakhirkan. Namun, pada beberapa kesempatan mubtada harus diakhirkan (Muakhar) dan Khabar harus didahulukan (Muqaddam).

Urgensi mempelajari ilmu naḥwu khususnya pada materi mubtada khabar adalah agar bisa memahami kaidah penyusunan kalimat dalam bahasa Arab. Bahasa Arab memiliki pola kalimat yang berbeda dengan bahasa Indonesia. Karena ia tidak hanya berbicara tentang susunan kata dalam suatu kalimat, tetapi juga berbicara keadaan huruf terakhir dari suatu kata yang ada pada kalimat. Dari hal tersebut pembelajaran ilmu nahwu menjadi sesuatu yang sangat penting bagi pegiat bahasa Arab. Oleh karena itu, sebagai guru bahasa Arab harus mampu menemukan model pembelajaran bahasa Arab yang aktif, efektif, komunikatif, efisien, inovatif dan menyenangkan.

Berdasarkan hal tersebut, kegiatan belajar mengajar memerlukan model pembelajaran yang sesuai. Model pembelajaran merupakan bentuk pembelajaran yang menggambarkan kegiatan dari awal sampai akhir yang disajikan secara khas oleh guru. Model pembelajaran merupakan bentuk pembelajaran yang menggambarkan kegiatan dari awal sampai akhir yang disajikan secara khas oleh guru. Model pembelajaran merupakan alat yang sangat penting bagi 
keberhasilan suatu proses pembelajaran. Tanpa model yang sesuai dan tepat tentu akan menjadi sulit dalam mencapai tujuan dan sasaran pendidikan yang diinginkan.

Menentukan model yang tepat untuk pembelajaran bukanlah suatu hal yang mudah, karena banyak kelebihan dan kekurangan yang harus dipertimbangkan. Dengan model yang sesuai dan tepat, maka diharapkan sasaran dan tujuan pembelajaran bahasa Arab dapat tercapai dengan maksimal.

Model pembelajaran menurut Trianto (dalam Afandi, 2013:15) merupakan suatu perencanaan atau pola yang digunakan sebagai pedoman dalam merencanakan pembelajaran di kelas atau pembelajaran tutorial. Model pembelajaran akan sangat berpengaruh terhadap pembelajaran bahasa. Hal inilah yang membuat pengajaran di sekolah mencari model pembelajaran yang cocok dalam mengembangkan pembelajaran bahasa.

Setelah peneliti melakukan praobservasi, dapat diketahui bahwa ilmu naḥwu khususnya mubtada khabar merupakan salah satu materi bahasa Arab yang dalam pelaksanaannya sulit untuk dipahami siswa. Tidak adanya inovasi dalam pembelajaran naḥwu, metode yang digunakan oleh guru kurang efektif dalam mengajarkan ilmu naḥwu. Dimana siswa hanya mendengarkan dan mengerjakan soal yang diperintah oleh guru tanpa mengetahui minat belajar seperti apa yang diinginkan siswa, dalam situasi ini mengakibatkan siswa cenderung lebih pasif dalam kegiatan belajar mengajar. Serta media yang digunakan guru dirasa monoton sehingga muncullah ketidaktertarikan siswa terhadap bahasa Arab, termasuk pada materi mubtada khabar.

Melihat kondisi demikian berdasarkan permasalahan-permasalahan yang nampak adanya di lapangan, peneliti mempunyai keinginan serta dan antusiasme untuk melakukan pengkajian terhadap model pembelajaran pada materi mubtada khabar.

MTs Al-Musyawarah merupakan sekolah berbasis Islam di bawah Kementerian Agama yang letaknya di jalan Baru Adjak no 158 Lembang. Sekolah ini menetapkan kurikulum bahasa Arab sebagai mata pelajaran yang wajib diikuti oleh peserta didik kelas VII. Peserta didik diharapkan mampu menguasai kemampuan dalam memahami gramatika bahasa Arab sesuai dengan kurikulum 2013 yang di dalamnya terdapat materi mubtada khabar dengan alokasi waktu 3 jam pelajaran/ minggu.

Akan tetapi, kondisi berbeda ada di MTs Al-Musyawarah Lembang kelas VII, di mana siswa sangat antusias terhadap bahasa Arab khususnya pada materi mubtada khabar, dikarenakan adanya upaya guru dengan menerapkan model pembelajaran discovery learning. Model 
ALSUNIYAT: Jurnal Penelitian Bahasa, Sastra, dan Budaya Arab

pembelajaran ini menurut Hosnan (2014:92) adalah salah satu model untuk mengembangkan cara belajar siswa aktif menemukan sendiri, menyelidiki sendiri, maka hasil yang diperoleh akan setia dan tahan lama dalam ingatan, tidak akan mudah dilupakan oleh siswa. Model pembelajaran ini juga melatih siswa bisa berpikir analisis dan mencoba memecahkan sendiri masalah yang dihadapi serta dapat meningkatkan pemahaman pada siswa.

Berdasarkan latar belakang di atas, peneliti bermaksud untuk menganalisis bagaimana penggunaan model pembelajaran discovery learning dalam ilmu nahwu khususnya pada materi mubtada khabar yang dilaksanakan di MTs Al-Musyawarah Lembang. Maka dari itu, peneliti mengambil judul "Penggunaan Model Pembelajaran Discovery Learning Pada Materi Mubtada khabar Kelas VII MTs Al-Musyawarah Lembang".

Erta Mahyudin (2014) membahas tentang penggunaan model pembelajaran discovery learning sebagai strategi pembelajaran bahasa Arab. Dalam penelitiannya disebutkan bagaimana discovery learning dapat diimplementasikan dalam semua tingkat kemampuan berbahasa, dengan tetap memperhatikan karakteristik setiap tingkatan. Berbeda dengan penelitian yang dilakukan oleh Ma'rifatul dkk. (2019) menjelaskan discovery learning dalam pembelajaran matematika yang menggunakan media komik. Dalam penelitiannya discovery learning menawarkan solusi untuk memudahkan siswa memecahkan persoalan pada mata pelajaran matematika. Adapula penelitian yang dilakukan oleh Ali dkk. (2016) menjelaskan tentang penggunaan model pembelajaran discovery learning pada pembelajaran anak sekolah dasar. Hal ini membuktikan bahwa discovery learning cocok digunakan pada siswa kelas rendah karena discovery learning lebih menarik dengan adanya percobaan.

Adapun persamaan penelitian yang hendak peneliti teliti dengan penelitian-penelitian tersebut yaitu sama-sama membahas penggunaan discovery learning dalam pembelajaran. Sedangkan perbedaannya terletak pada mata pelajaran dan media yang di gunakan. Peneliti lebih fokus pada pelajaran bahasa Arab khususnya pada materi mubtada khabar dengan menggunakan media kartu soal. Penerapan discovery learning pada umumnya masih banyak ditemukan dalam kegiatan pembelajaran di sekolah.

Penggunaan discovery learning penting diperhatikan dalam kegiatan pendidikan, khususnya saat kegiatan pembelajaran berlangsung. Dengan memerhatikan model pembelajaran yang tepat, maka hasil belajar mengajar dapat berjalan efektif dan efisien. Dengan demikian, masalah ini dianggap penting untuk diangkat ke permukaan melalui karya 
ilmiah untuk diteliti dan dicarikan solusinya karena berada di ruang lingkup bahasa Arab dalam wilayah pendidikan.

\section{METODE}

Penelitian yang digunakan adalah analisis kualitatif. Adapun metode yang digunakan peneliti untuk menjawab rumusan masalah yang ditulis yaitu metode deskriptif. Metode deskriptif digunakan untuk mengumpulkan data-data yang berkaitan dengan penggunaan model pembelajaran discovery learning pada materi mubtada khabar. Dalam penelitian ini, sampel dari populasi yaitu siswa kelas VII C di MTs Al-Musyawarah Lembang sebanyak 30 orang. Pada pengambilan sampel penelitian ini peneliti menggunakan teknik sampling jenuh yaitu semua populasi menjadi objek sampel. Penelitian ini dilakukan di MTs Al-Musyawarah Lembang yang terletak di Jalan Baru Adjak No. 185.

Dalam penelitian ini, peneliti melakukan observasi, dimana peneliti hanya mencatat dan menganalisis kegiatan guru dan siswa dalam proses pembelajaran di kelas. Kemudian peneliti mewawancarai guru mata pelajaran bahasa Arab dan siswa kelas VII MTs Al-Musyawarah Lembang yang berkaitan dengan perencanaan pembelajaran menggunakan model pembelajaran discovery learning, proses kegiatan pembelajaran menggunakan model pembelajaran discovery learning, dan evaluasi pembelajaran. Dan studi dokumentasi dalam penelitian ini yaitu hasil belajar siswa kelas VII MTs Al-Musyawarah Lembang dalam mata pelajaran bahasa Arab khususnya pada materi mubtada khabar.

Setelah data terkumpul, pada tahap analisis data ini, peneliti secara kualitatif berupaya menangani langsung masalah yang terkandung dalam data. Karena penelitian ini merupakan penelitian mengenai analisis kualitatif deskriptif maka prosedur yang digunakan adalah sebagai berikut: (1) menganalisis perencanaan dengan menggunakan model pembelajaran discovery learning pada materi mubtada khabar; (2) menganalisis proses dengan menggunakan model pembelajaran discovery learning pada materi mubtada khabar; (3) menganalisis evaluasi dengan menggunakan model pembelajaran discovery learning pada materi mubtada khabar.

\section{HASIL DAN PEMBAHASAN}

Adapun data-data yang didapatkan oleh peneliti adalah tentang perencanaan pembelajaran, proses pembelajaran dan evaluasi pembelajaran bahasa Arab khususnya pada materi mubtada khabar di kelas VII MTs Al-Musyawarah Lembang tahun ajaran 2018-2019 sebagai berikut. 


\section{Perencanaan pembelajaran bahasa Arab pada materi mubtada khabar dalam menggunakan model pembelajaran discovery learning}

\section{a) Kurikulum}

MTs Al-Musyawarah Lembang melaksanakan Kurikulum Departemen Agama. Kurikulum merupakan suatu rencana yang disusun untuk melancarkan proses belajar mengajar di bawah bimbingan dan tanggung jawab sekolah atau lembaga pendidikan beserta staf pengajaran agar tercapainya tujuan pendidikan. Adapun manfaat kurikulum bagi sekolah yang diungkapkan oleh Kurniawan \& Eddy (2017:16) bahwa kurikulum dijadikan sebagai alat untuk mencapai suatu tujuan pendidikan, baik itu dalam tujuan nasional, institusional, kurikuler, maupun dalam tujuan instruksional. Dengan adanya suatu kurikulum maka tujuan-tujuan pendidikan yang diinginkan oleh sekolah tertentu dapat tercapai.

Sebelum pelaksanaan pembelajaran mubtada khabar guru menyiapkan bahan ajar, mempelajari materi yang akan disampaikan. Guru juga harus menyiapkan perencanaan pembelajaran yaitu menyiapkan media pembelajaran berupa papan tulis, spidol, kartu kalimat, lembar kerja siswa dan buku ajar. Kegiatan model discovery learning ini perlu perencanaan pembelajaran yang matang. Dengan kata lain, pemilihan materi ajar, persiapan media pembelajaran, dan persiapan penilaian hasil belajar harus terencana dengan rapi. Apabila perencanaan yang dilakukan dengan baik, maka setengah keberhasilan sudah dapat tercapai, setengahnya lagi terletak pada pelaksanaan.

\section{b) Silabus}

Berdasarkan hasil observasi dan wawancara dengan guru bahasa Arab bahwa silabus tidak dibuat oleh guru melainkan sudah tersedia di sekolah. Dengan demikian, guru hanya menyusun dan mengembangkannya ke dalam RPP berdasarkan bahan ajar yang sudah disiapkan.

Menurut Dominika (2009:6) menjelaskan bahwa silabus merupakan rencana pembelajaran jangka panjang pada suatu atau kelompok mata pelajaran tertentu yang mencakup kompetensi dasar, materi pembelajaran, kegiatan pembelajaran, indikator, penilaian, alokasi waktu dan sumber belajar.

Sehingga dapat disimpulkan bahwa silabus tidak dibuat oleh guru melainkan sudah tersedia di sekolah dan guru hanya mengembangkan ke dalam RPP berdasarkan bahan ajar yang sudah disiapkan. 


\section{c) Rencana Pelaksanaan Pembelajaran}

Ismawati (2012:1) mengemukakan bahwa perencanaan pembelajaran adalah segala bentuk kegiatan yang dibuat, dirancang, dan dipersiapkan untuk mencapai tujuan proses belajar mengajar secara optimal. Perencanaan haruslah dirancang dengan baik karena akan menentukan kemana harus pergi dan mengidentifikasikan persyaratan yang diperlukan dengan cara yang paling efektif dan efisien.

Hal ini sesuai dengan hasil wawancara guru bahasa Arab di MTs Al-Musyawarah Lembang bahwa guru mempersiapkan perencanaan pembelajaran dengan baik yaitu dengan adanya Silabus dan RPP.

Rencana pelaksanaan pembelajaran minimal ada lima komponen pokok, yaitu komponen tujuan pembelajaran, materi pelajaran, metode, media dan sumber pembelajaran serta komponen evaluasi. Hal ini seperti yang digariskan oleh Nomor 19 Tahun 2005 Bab IV Pasal 20 yang menyatakan bahwa perencanaan proses pembelajaran meliputi silabus dan rencana pelaksanaan pembelajaran yang memuat sekurangkurangnya tujuan pembelajaran, materi ajar, metode pengajaran, sumber belajar, dan penilaian hasil belajar. (Sanjaya, 2012:59).

Dari hasil wawancara dan observasi ditemukan bahwa RPP pembelajaran pada materi mubtada khabar di MTs Al-Musyawarah Lembang memuat tentang kompetensi dasar memuat memahami secara sederhana unsur kebahasaan, struktur teks dan unsur budaya dari teks terkait yang sesuai dengan konteks penggunaannya dengan struktur kalimat tentang mubtada khabar dan menyusun teks sederhana dengan memperhatikan struktur teks mubtada khabar.

Indikator pencapaian memuat memahami kaidah mubtada khabar sesuai dengan struktur kebahasaan yang benar, mengidentifikasi contoh mubtada khabar dalam kalimat bahasa Arab sesuai dengan konteks yang benar, dan menyusun kalimat sederhana dengan menggunakan mubtada khabar sesuai dengan kaidah kebahasaan yang benar. Metode pembelajaran yang digunakan yaitu menyimak, țarīqah mubāsyarah, scramble kalimat dan model pembelajaran discovery learning. Media dan sumber belajar yang digunakan yaitu papan tulis, spidol, tabel tarkīb, kartu kalimat dan LKS siswa.

Kegiatan pembelajaran terdiri dari tiga tahap, yaitu kegiatan pendahuluan, kegiatan inti dan penutup. Dan penilaian hasil belajar terdiri dari tes lisan dan tes tulisan. Namun, pada proses pembelajaran berlangsung, RPP tidak dijadikan acuan sepenuhnya dalam 
ALSUNIYAT: Jurnal Penelitian Bahasa, Sastra, dan Budaya Arab

kelangsungan pembelajaran, melainkan tergantung kepada situasi dan kondisi siswa di kelas.

\section{Proses pembelajaran bahasa arab pada materi mubtada khabar dalam menggunakan model pembelajaran discovery learning}

Menurut Suryosubroto (2009:2) Proses belajar mengajar merupakan inti dari kegiatan pendidikan di sekolah. Agar tujuan pendidikan dan pembelajaran berjalan dengan benar maka perlu pengadministrasian kegiatan-kegiatan belajar mengajar yang lazim disebut administrasi kurikulum. Adapun James (dalam Suryosubroto, 2009:2) menjelaskan bahwa tugas dan peranan guru antara lain: menguasai dan mengembangkan materi pelajaran, merencanakan dan mempersiapkan pelajaran, mengontrol dan mengevaluasi kegiatan siswa.

Hal ini sesuai dengan hasil observasi dan wawancara bahwa proses pembelajaran mubtada khabar dalam menggunakan model pembelajaran discovery learning berlangsung 40 menit yang terdiri dari dari tiga tahap, yaitu kegiatan pendahuluan, kegiatan inti dan penutup.

Pada kegiatan pendahuluan, guru hadir dan memulai pembelajaran dengan tepat waktu. Guru membuka pembelajaran dengan salam, menanyakan kabar dan menanyakan pelajaran apa sekarang dengan menggunakan bahasa Arab, mengecek kehadiran siswa sambil memperhatikan siswa yang dipanggil namanya, mengulang materi sebelumnya, menginformasikan materi yang akan dipelajari, memberikan motivasi belajar kepada siswa agar siswa antusias mengikuti pembelajaran, menyampaikan tujuan pembelajaran yang akan dicapai, serta menulis hal-hal penting sepeti hari, tanggal, dan tema pelajaran yang akan dipelajari. Dan tidak lupa juga guru mempersiapkan psikis dan fisik siswa untuk mengikuti pembelajaran bahasa Arab dengan baik.

Pada kegiatan inti, meminta siswa mengamati struktur kalimat tentang mubtada khabar dan mengaitkan materi tersebut dengan contoh-contoh yang konkret agar siswa mudah memahami materi. Kemudian memulai pembelajaran mubtada khabar dalam menggunakan model pembelajaran discovery learning dengan langkah-langkah:

1) Guru meminta siswa untuk duduk berkelompok yang telah ditentukan.

2) Guru memberikan beberapa kartu yang berisikan kata-kata acak dari struktur kalimat mubtada khabar beserta lembar kerja kepada masing masing kelompok.

3) Guru meminta siswa untuk menerjemahkan kata-kata yang diberikan. 
4) Guru memberikan kesempatan kepada untuk bertanya.

5) Guru membimbing siswa mencari dan menemukan informasi baru tentang mubtada khabar.

6) Guru meminta siswa berdiskusi untuk menyusun kata-kata yang diberikan menjadi kalimat yang baik dan benar.

7) Guru meminta siswa untuk mengidentifikasi mubtada khabar pada kalimat yang telah disusun.

8) Guru meminta siswa untuk mempresentasikan tentang mubtada khabar.

Pada kegiatan penutup ini, guru membimbing siswa untuk memberikan kesimpulan materi yang telah dibahas. Kemudian guru memberikan penugasan terstruktur individu atau pekerjaan rumah. Guru menutup proses pembelajaran dengan tepat waktu dan mengucapkan salam.

Berdasarkan pemaparan di atas, dapat disimpulkan bahwa proses pembelajaran pada materi mubtada khabar dalam menggunakan model pembelajaran discovery learning sudah sesuai dari mulai kegiatan pendahuluan, kegiatan inti, dan kegiatan penutup, serta memiliki model pembelajaran yang inovatif sehingga pembelajaran di kelas menjadi hidup dan siswa aktif selama proses pembelajaran. Model discovery learning yang digunakan ini berpengaruh baik terhadap kemampuan siswa dalam memahami materi mubtada khabar.

\section{Evaluasi pembelajaran bahasa arab pada materi mubtada khabar dalam menggunakan}

\section{model pembelajaran discovery learning}

Menurut Matsna dan Mahyudin (2012:1) evaluasi adalah kegiatan atau proses mengukur dan selanjutnya menilai sampai dimanakah tujuan yang telah dirumuskan. Secara umum dapat dikatakan, evaluasi pengajaran adalah penilaian terhadap pertumbuhan dan kemajuan peserta didik ke arah tujuan-tujuan yang telah ditetapkan.

Berdasarkan hasil wawancara dengan guru mata pelajaran bahasa Arab kelas VII, teknik evaluasi yang digunakan dalam pembelajaran bahasa Arab adalah teknik evaluasi formatif berupa:

a. Tes lisan: Guru membuat pertanyaan yang harus dijawab siswa dan hasilnya dijelaskan di depan kelas serta menjelaskan kembali materi apa yang telah dijelaskan. Misalnya, guru menunjuk salah satu atau dua orang siswa untuk maju ke depan kelas dan menjawab pertanyaan dari guru beserta penjelasannya. 
ALSUNIYAT: Jurnal Penelitian Bahasa, Sastra, dan Budaya Arab

b. Tes tulisan: Untuk memperkuat pemahaman siswa terhadap materi mubtada khabar, guru memberikan tugas terstruktur kepada siswa.

Adapun hasil penelitian yang peneliti temukan melalui data dokumentasi bahwa hasil evaluasi pembelajaran pada materi mubtada khabar dalam menggunakan model pembelajaran discovery learning mampu memacu siswa dalam memahami materi tersebut dan dapat membedakan mubtada khabar.

\section{SIMPULAN}

Berdasarkan hasil penelitian dan pembahasan dapat ditarik kesimpulan bahwa perencanaan pembelajaran bahasa Arab pada materi mubtada khabar dalam menggunakan model pembelajaran discovery learning meliputi kurikulum Departemen Agama.

Dalam pengaplikasian kurikulumnya, terdapat silabus yang telah disediakan di sekolah sehingga guru hanya menyusun dan mengembangkannya ke dalam rencana pelaksanaan pembelajaran (RPP). RPP yang telah dibuat guru belum maksimal dan tidak dijadikan acuan karena pembelajaran tergantung dengan situasi dan kondisi siswa. Selain itu, perencanaan yang dilakukan guru sudah cukup baik, yaitu menyiapkan bahan ajar, mempelajari materi yang akan disampaikan, menguasai materi yang akan disampaikan dan menyiapkan media yang akan digunakan, seperti spidol, papan tulis, kartu kalimat, dan tabel tarkib.

Proses pembelajaran bahasa Arab pada materi mubtada khabar dalam menggunakan model pembelajaran discovery learning. Dalam pembelajaran bahasa Arab di MTs AlMusyawarah Lembang dimulai dari kegiatan pendahuluan, kegiatan inti yang mana menggunakan model pembelajaran discovery learning, dan kegiatan penutup. Proses pembelajaran bahasa Arab pada materi mubtada khabar dianggap maksimal karena pematerian tersampaikan dan dapat memotivasi siswa dalam semangat belajar, serta siswa dapat fokus selama pembelajaran berlangsung, sehingga siswa dapat mengaplikasikan materi dengan cukup baik.

Evaluasi pembelajaran bahasa arab pada materi mubtada khabar dalam menggunakan model pembelajaran discovery learning dilaksanakan cukup baik dengan teknik penilaian yaitu: a.) Tes lisan: guru membuat pertanyaan yang harus dijawab siswa dan hasilnya di jelaskan di depan kelas serta menjelaskan kembali materi apa yang telah dijelaskan. Misalnya, guru menunjuk salah satu atau dua orang siswa untuk maju ke depan kelas dan menjawab pertanyaan dari guru beserta penjelasannya. b.) Tes tulisan: Untuk memperkuat pemahaman siswa terhadap materi mubtada khabar, guru memberikan tugas terstruktur kepada siswa. 


\section{DAFTAR PUSTAKA}

Afandi, M, dkk. (2013). Model dan Metode Pembelajaran di Sekolah. Semarang: Unissula Press.

Al-Ghalayini, Mushtafa. (2005). Jami' al-Durus al-'Arabiyyah. Kairo: Dar al-Hadîts.

Al-Jurjani, Muhammad bin Ali. (2003). Al-Ta'rifat. Beirut: Dar Al-Kutub Al-Ilmiyyah.

Dominika, Maria. (2009). Pengembangan Silabus dan Rencana Pelaksanaan PembelajaranDalam KTSP. Universitas Negeri Yogyakarta.

Hosnan, M. (2014). Pendekatan Saintifik dan Kontekstual dalam Pembelajaran Abad 21. Jakarta: Ghalia Indonesia.

Ismawati, Esti. (2012). Perencanaan Pengajaran Bahasa. Yogyakarta: Ombak.

Kurniawan, 0 \& Eddy, Noviana. (2017). Penerapan Kuirkulum 2013 Dalam Meningkatkan Keterampilan, Sikap, dan Pengetahuan. Jurnal Primary Program Studi Pendidikan Guru Sekolah Dasar, 6(2), 389-396.

Matsna, Moh \& Erta, Mahyudin. (2012). Pengembangan Evaluasi dan Tes Bahasa Arab. Tangerang Selatan: Al-Kitabah.

Sanjaya, Wina. (2012). Strategi Pembelajaran Berorientasi Standar Proses Pendidikan. Jakarta: Kencana.

Suryosubroto. (2009). Proses Belajar Mengajar di Sekolah. Jakarta: PT. Rhineka Cipta. 